\title{
Seasonal assessment of some heavy metal pollution and Metallothionein gene expression in cultured Oreochromis niloticus
}

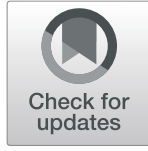

\author{
Shenouda M. Girgis ${ }^{1 *}$ D, Dalia M. Mabrouk1, Magdy I. Hanna² and Amira Abd ElRaouf ${ }^{1}$
}

\begin{abstract}
Background: The present study was planned to estimate the heavy metal concentrations in water samples and fish tissue residue (liver and muscle) of cultured Oreochromis niloticus as well as metallothionein (MT) gene expression in fish liver. Fish samples were collected from different private fish cultures in Kafr El-Sheikh governorate during April 2018-April 2019 in order to assess the public health risks associated with consuming cultured fish. Therefore, we investigated the concentrations of four metal elements (cadmium [Cd], copper [Cu], lead [Pb], and zinc [Zn]) in both fish tissues (muscle and liver) and water samples during the four seasons. Other water parameters (pH value, chemical oxygen demand, dissolved oxygen, alkalinity, total hardness, ammonia, and nitrite) were also determined.

Results: NH3 values were above recommended limits mostly along the year. The trend of metal mean contents found in the fish were in decreasing order of $\mathrm{Zn}>\mathrm{Cu}>\mathrm{Pb}>\mathrm{Cd}$, and the liver showed greater accumulation than muscle. The highest amounts of metals accumulated in fish liver and muscle were recorded in winter and autumn, respectively, while the lowest amount was recorded in summer. Regarding fish muscle which is the edible part consumed by human, the concentration of studied metals was within the safe limits for seafood except for Pb. MT showed a significant high level in response to metals accumulated in fish liver. A positive correlation occurred between MT levels and $\mathrm{Cu}$ and $\mathrm{Pb}$ concentrations across different seasons.

Conclusion: In conclusion, MT expression levels seem to be sensitive to the heavy metals in natural habitats making it a powerful biomarker of heavy metals pollution in fish cultures. In addition, cultured fish in this study could be unfit for human consumption due to a high level of $\mathrm{Pb}$ in the edible part of fish. Therefore, greater attention should be set to Pb sources accumulated in cultured fish in Kafr El-Sheikh governorate.
\end{abstract}

Keywords: Metallothionein, Gene expression, Heavy metals, Oreochromis niloticus, Liver, Muscle

\section{Introduction}

Metal pollution is an important worldwide problem, which is growing at an alarming rate. Despite progress made in environmental waste management, heavy metals still pose immense health hazards to humans and biota. Unlike other classes of pollutants, which can be biodegraded and destroyed, metals are non-biodegradable (Wepener et al. 2001) and can neither be created nor destroyed. An accelerated release of heavy metals into the aquatic environment poses serious water pollution problems because of their toxicity (Tulasi et al. 1989),

\footnotetext{
* Correspondence: shenoudag2009@hotmail.com

'Department of Cell Biology, Genet. Eng.\& Biotech. Res. Div., National

Research Centre, 33 El-Bohouth St. Dokki, Giza P.O. 12622, Egypt

Full list of author information is available at the end of the article
}

persistence, and bioaccumulation in food chains (Rishi and Jain 1998). Heavy metal accumulation in the environment could be because of acid mine drainage, industrial emissions, traffic, domestic sewage, storm water, atmospheric deposition, and building materials (Xia et al. 2011). In developing countries, the rapid increase in domestic, agricultural, and industrial activities add heavy metals loads in the air, water, and soil (Solaraj et al. 2010). The accumulation of heavy metals in fish gill, muscle, and liver has a great attention because of the potential toxic effects of such substances not only on fish, but also on human consumption (Burger and Gochfeld 2005). So, heavy metal load in fish has become an important worldwide threat, not only for fish but also for human as a result of the health risks associated with fish consumption (Begum et al. 2013). 
Metallothioneins (MTs) are a family of low molecular weight cytosolic proteins that contain highly conserved cysteinyl residues. These residues allow MT to bind, transport, and store various essential ( $\mathrm{Zn}$ and $\mathrm{Cu}$ ) and non-essential ( $\mathrm{Cd}$ and $\mathrm{Hg}$, mercury) heavy metals via thiolate bonding (Isani and Carpenè 2014). The change in the expression level of metallothionein gene in fish is used as a biomarker for heavy metal pollution in the ecosystem (Struve et al. 2005). MT also is considered as an indicator for degradation of environmental conditions and specific measures of the toxic, carcinogenic, and mutagenic compounds in the biological materials (Verlecar et al. 2006).

Therefore, our aim to estimate the heavy metal concentration in water samples and fish tissues (liver and muscle) of cultured Oreochromis niloticus as well as MT gene expression in fish liver in order to assess the public health risks associated with consuming cultured fish.

\section{Methods}

\section{Study area}

Random fish samples (200) were collected from private fish cultures in Kafr El-Sheikh governorate, Egypt, along the four seasons (autumn, winter, spring, and summer).

\section{Sampling collection and preparation Water sample and analysis}

Twelve water samples were collected during the study period (April 2018-April 2019). One liter of water samples at each pond was placed in polyethylene bottles previously washed with acid $\left(0.01 \mathrm{~N} \mathrm{HNO}_{3}\right)$ and rinsed by distilled water, then placed in a cooler at $4{ }^{\circ} \mathrm{C}$ and transferred to the lab for further analysis.

\section{Physico-chemical analysis of water samples}

The investigated physico-chemical analysis was $\mathrm{pH}$, chemical oxygen demand (COD), dissolved oxygen, alkalinity, total hardness, total kjeldahl nitrogen (TKN), ammonia $\left(\mathrm{NH}_{3}\right)$, and nitrite $\left(\mathrm{NO}_{2}\right)$. Detection of some heavy metals $(\mathrm{Cd}, \mathrm{Cu}, \mathrm{Pb}$, and $\mathrm{Zn})$ was done using flame atomic absorption spectrophotometer. All analyses were carried out according to the American Public Health Association for the Examination of Water and Wastewater (APHA 2012).

\section{Heavy metal residues}

Liver and muscle tissues were taken, then placed in polyethylene bags and stored at $-20^{\circ} \mathrm{C}$ until analysis. About $1 \mathrm{~g}$ from previously oven-dried muscle or liver tissues was ignited and digested with concentrated $\mathrm{HNO}_{3}$ and $\mathrm{HCl}$ according to procedures recommended by AOAC (2005) using Flame Atomic Absorption Spectrophotometer (Thermo Electron Corporation S Series AA Spectrometer).

\section{Metal pollution index (MPI)}

The metal pollution index (MPI) was used to compare the total metal contents of muscle and liver of the studied fish in different year seasons. MPI was calculated with the formula: $\mathrm{MPI}=(\mathrm{M} 1 \times \mathrm{M} 2 \times \mathrm{M} 3 \times$ $\ldots \times \mathrm{Mn})^{1 / \mathrm{n}}$, where $\mathrm{Mn}$ is the concentration of metal expressed in microgram per gram of wet weight, according to Usero et al. (1997).

\section{Metallothionein gene (MT) expression analysis RNA extraction and CDNA synthesis}

Total RNA (ribonucleic acid) was extracted from liver tissue samples using Easy red total RNA extraction kit (Intronbio, Korea) according to the manufacturer's instructions. RNA was run on $1.5 \%$ formaldehyde denaturing agarose gel to assess its integrity. RNA purity and concentration were measured using NanoDrop ${ }^{\text {Tu }} 1000$ Spectrophotometer (Thermo Fisher Scientific, USA). RNase-free DNase kit (Promega) was used to remove any DNA (deoxyribonucleic acid) contamination from extracted RNA. DNase-treated RNA was reverse-transcribed into First-strand cDNA (complementary DNA) using HiSenScript TM cDNA kit (Intronbio, Korea) in a $20 \mu \mathrm{l}$ reaction containing $1000 \mathrm{ng}$ total RNA.

\section{Real-time PCR analysis}

Metallothionein gene, as a biomarker for water pollution with heavy metals, and beta actin ( $\beta$-Actin), as internal control, were used in the present study; primers were obtained from Macrogen (Grand Island, NY), and sequences are shown in Table 1. TOPreal TMqPCR 2X PreMIX (SYBR Green with low ROX) (Enzynomics) was used to perform qRT-PCR (polymerase chain reaction) with $1 \mu \mathrm{l}$ cDNA (total $50 \mathrm{ng}$ RNA) in a $20 \mu \mathrm{l}$ reaction mixure using Stratagene Mx3000P Real-Time PCR System (Agilent Technologies, USA). PCR conditions included $15 \mathrm{~min}$ at $95^{\circ} \mathrm{C}$, followed by 40 cycles at $95^{\circ} \mathrm{C}$ for $15 \mathrm{~s}$, at $60^{\circ} \mathrm{C}$ for $15 \mathrm{~s}$, and $72^{\circ} \mathrm{C}$ for $30 \mathrm{~s}$. Melting curve analyses were performed following the end of each reaction to confirm specific PCR products. Metallothionein gene expression levels normalized to $\beta$-actin were calculated using the $2^{-\Delta \Delta C t}$ method (Livak and Schmittgen 2001).

\section{Statistical analysis}

The results were represented as mean \pm standard error (SE) values. Statistical analysis of data was carried out using SPSS 14 software package. Data analysis was done using the one-way analysis of variance (ANOVA) with post hoc Tukey HSD analysis to compare the data among seasons at the level of significance $\leq 0.05$. Correlation between hepatic MT expression levels and metal concentrations in fish across different seasons were evaluated using the Pearson correlation coefficient. 
Table 1 Name, accession number, primer sequence, and product size for genes used for real-time PCR analysis

\begin{tabular}{llll}
\hline Gene & $\begin{array}{l}\text { Accession } \\
\text { number }\end{array}$ & $\begin{array}{l}\text { Nucleotide sequence } \\
5^{\prime}-3^{\prime}\end{array}$ & $\begin{array}{l}\text { Size of PCR } \\
\text { product (bp) }\end{array}$ \\
\hline Metallothionein & XM_ & CTGCAACTGCGGAGGA & 136 \\
& 003447045.5 & $\begin{array}{l}\text { GGTGTCGCATGTCTT } \\
\text { CCTT }\end{array}$ & \\
\multirow{3}{*}{ B-Actin } & XM_ & TGTGTGGTGTGGGT & 136 \\
& 003443127.5 & GTTTG & \\
& & CAGCAAGCAGGAGTAC \\
& GATGAG & \\
& &
\end{tabular}

\section{Results}

\section{Water parameters and heavy metal concentration}

Seasonal variations in water parameter and heavy metal concentrations are presented in Table 2 in reference to the permissible limits of water parameter and heavy metal concentrations (mg/l): $\mathrm{pH} 7-8.5, \mathrm{COD} \leq 10$, D.O $\geq 5$, alkalinity $20-150, \mathrm{NH} 3 \leq 0.5, \mathrm{Cd} \leq 0.003, \mathrm{Cu} \leq 1$, $\mathrm{Pb} \leq 0.5$, and $\mathrm{Zn} \leq 2$ (Egyptian Environmental Law 48decision 92, 2013). $\mathrm{pH}$ did not vary noticeably between summer, spring, and autumn, but is higher in winter (8.03). A detectable elevation in chemical oxygen demand (COD) was recorded in summer $(80 \mathrm{mg} / \mathrm{l})$. Autumn showed the highest nitrite (NO2) concentration $(1.2 \mathrm{mg} / \mathrm{l})$ compared with other seasons. Ammonia exceeded the permissible limits in all seasons, in summer $(4.8 \mathrm{mg} / \mathrm{l})$, spring $(3.6 \mathrm{mg} / \mathrm{l})$, autumn $(3.2 \mathrm{mg} / \mathrm{l})$, and winter $(1.1 \mathrm{mg} / \mathrm{l})$. The pattern of alkalinity and total hardness in different seasons was in decreasing order as follow: autumn $>$ summer $>$ spring $>$ winter. The highest value of dissolved oxygen (DO) was recorded in winter $(5.05 \mathrm{mg} / \mathrm{l})$, and the lowest value recorded in summer $(4.3 \mathrm{mg} / \mathrm{l})$. The maximum values of total kjeldahl nitrogen were recorded in summer $(15.7 \mathrm{mg} / \mathrm{l})$. All heavy metal concentrations in water were under permissible limits.

\section{Heavy metals in muscle tissues}

As shown in Table 3, the results revealed that the highest levels of $\mathrm{Zn}$ were recorded in autumn $(50 \mu \mathrm{g} / \mathrm{g})$ that exceeded the permissible limits and the least levels were recorded in summer $(10.7 \mu \mathrm{g} / \mathrm{g}) . \mathrm{Cd}$ showed extremely low levels ( $<0.05 \mu \mathrm{g} / \mathrm{g}$ ) across the four seasons. The highest levels of $\mathrm{Pb}$ and $\mathrm{Cu}$ were recorded in autumn followed by winter and spring $(1.8,1.2$, and $1.15 \mu \mathrm{g} / \mathrm{g}$, respectively). $\mathrm{Pb}$ levels were above the permissible limits (except for summer) while $\mathrm{Cu}$ levels were below limits across the four seasons.

\section{Heavy metals in liver tissues}

As shown in Table 4, Zn showed low levels across seasons except for autumn, where the levels $(60.1 \mu \mathrm{g} / \mathrm{g})$ exceeded permissible limits. It was noticeably that $\mathrm{Pb}$ levels exceeded permissible limits across seasons (except for summer), where the highest levels for $\mathrm{Pb}$ were recorded in autumn $(2.1 \mu \mathrm{g} / \mathrm{g})$ followed by spring and winter $(1.2$ and $1.6 \mu \mathrm{g} / \mathrm{g}$, respectively). $\mathrm{Cu}$ levels were markedly high and exceeded permissible limits in spring $(68.8 \mu \mathrm{g} / \mathrm{g})$ followed by winter $(36.3 \mu \mathrm{g} / \mathrm{g})$, while they were below limits in summer and autumn (15.8 and $28.6 \mu \mathrm{g} / \mathrm{g})$. Cd showed extremely low levels, except in winter $(5.6 \mu \mathrm{g} / \mathrm{g})$ which exceeded permissible limits.

\section{MPI in liver and muscle tissue}

As revealed in Fig. 1, the highest metal pollution index (MPI) in the liver was that for fishes collected in winter and in muscle were in autumn, while the least MPI in both tissues was that for fishes collected in summer. On

Table 2 Water parameters (mg/l) and seasonal variations of heavy metals concentrations $(\mathrm{mg} / \mathrm{l})$ in three water samples per season of fish cultures in Kafr El-Sheikh governorate

\begin{tabular}{|c|c|c|c|c|c|}
\hline Water parameter/heavy metal & Winter & Spring & Autumn & Summer & Permissible limits \\
\hline $\mathrm{pH}$ value & 8.03 & 7.33 & 7.62 & 7.5 & $7-8.5$ \\
\hline Temperature & $18+0.5^{\circ} \mathrm{C}$ & $20+0.5^{\circ} \mathrm{C}$ & $22+1^{\circ} \mathrm{C}$ & $25+1{ }^{\circ} \mathrm{C}$ & \\
\hline Chemical oxygen demand (COD) (mg/l) & 10 & 20 & 30 & 35 & $\leq 10$ \\
\hline Dissolved oxygen (DO) (mg/l) & 5.05 & 4.59 & 4.6 & 4.3 & $\geq 5$ \\
\hline Alkalinity (mg/l) & 140 & 120 & 110 & 90 & $20-150$ \\
\hline Total hardness (mg/l) & 70 & 90 & 175 & 230 & 30-180 (Santhosh and Singh 2007) \\
\hline Ammonia $\left(\mathrm{NH}_{3}\right)(\mathrm{mg} / \mathrm{l})$ & 1.1 & 3.6 & 3.2 & 4.8 & 0.5 \\
\hline Nitrite $\left(\mathrm{NO}_{2}\right)(\mathrm{mg} / \mathrm{l})$ & 0.42 & 0.3 & 0.4 & 0.3 & $<0.2$ (OATA 2008) \\
\hline Cadmium & $<0.001$ & $<0.001$ & $<0.001$ & $<0.001$ & $\leq 0.003$ \\
\hline Copper & $<0.01$ & $<0.01$ & $<0.01$ & $<0.01$ & $\leq 1$ \\
\hline Lead & $<0.001$ & $<0.001$ & $<0.001$ & $<0.001$ & $\leq 0.5$ \\
\hline Zinc & $<0.001$ & $<0.001$ & $<0.001$ & 0.59 & $\leq 2$ \\
\hline
\end{tabular}

Data represented as an average of three samples 
Table 3 Seasonal variations of heavy metals concentrations ( $\mu \mathrm{g}$ / $\mathrm{g}$ dry weight) in muscle tissue of Oreochromis niloticus

\begin{tabular}{lllll}
\hline Heavy metal & Winter & Spring & Autumn & Summer \\
\hline Cadmium & $<0.05$ & $<0.05$ & $<0.05$ & $<0.05$ \\
Copper & $1 \pm 0.02^{\mathrm{b}}$ & $0.97 \pm 0.05^{\mathrm{b}}$ & $2.2 \pm 0.1^{\mathrm{a}}$ & $<0.05$ \\
Lead & $1.2 \pm 0.08^{\mathrm{b}}$ & $1.15 \pm 0.8^{\mathrm{b}}$ & $1.80 .05^{\mathrm{a}}$ & $<0.05$ \\
Zinc & $17.9 \pm 0.6^{\mathrm{bc}}$ & $21.4 \pm 0.9^{\mathrm{b}}$ & $50 \pm 2^{\mathrm{a}}$ & $10.7 \pm 0.32^{\mathrm{c}}$
\end{tabular}

Data are shown as mean \pm SEM; $(n=5)$; mean values with unlike superscript letters were significantly different $(p \leq 0.05)$

FAO (1983) limits in fresh muscle (mg/kg): $\mathrm{Cd}(0.5), \mathrm{Cu}(30), \mathrm{Pb}(0.5)$, and Zn (30)

EOS (1993) MPL limits in fish (mg/kg): Cd (0.5), Cu (20), Pb (2), and Zn (40)

the other hand, MPI in liver tissue was greatly higher than MPI in muscle.

\section{MT expression levels in the liver}

The mRNA expression levels of MT gene relative to the $\beta$-actin gene were shown in Fig. 2, where the melting curves showed single and sharp peaks confirming the specificity of the primers and accuracy of results. The results from the Pearson correlation (Table 5) displayed a significant positive correlations $(p<0.05)$ for $\mathrm{MT}-\mathrm{Cu}$ and MT-Pb, but exceptional for MT-Zn.

Real-time PCR results (Fig. 3) also showed that liver tissue of Oreochromis niloticus displayed a significant increase $\left(p^{<} 0.05\right)$ in MT expression levels during all seasons, except summer. The highest MT mRNA levels were recorded in spring and winter followed by autumn. Meanwhile, liver tissue of fish collected in summer showed the least MT mRNA levels.

\section{Discussion}

According to the results, heavy metals in water of fish culture were found to be below detection limits. In addition, in all seasons, the $\mathrm{pH}$ of the water was measured to be slightly alkaline which is considered as unfavorable conditions for the solubility of metals so, it was not expected to find metals in water samples, while the heavy metals were deposited in the sediments and accumulated in fishes (Ayas et al. 2007).

Table 4 Seasonal variations of heavy metals concentrations ( $\mu \mathrm{g} /$ $\mathrm{g}$ dry weight) in liver tissue of Oreochromis niloticus

\begin{tabular}{lllll}
\hline Heavy metal & Winter & Spring & Autumn & Summer \\
\hline Cadmium & $5.6 \pm 0.23^{\mathrm{a}}$ & $<0.05$ & $<0.05$ & $<0.05$ \\
Copper & $36.3 \pm 1.3^{\mathrm{b}}$ & $68.8 \pm 1.9^{\mathrm{a}}$ & $28.6 \pm 0.17^{\mathrm{b}}$ & $15.8 \pm 2.6 \mathrm{c}$ \\
Lead & $1.6 \pm 0.01^{\mathrm{b}}$ & $1.2 \pm 0.05^{\mathrm{c}}$ & $2.1 \pm 0.006^{\mathrm{a}}$ & $<0.05$ \\
Zinc & $3.8 \pm 0.01^{\mathrm{c}}$ & $18.8 \pm 0.3^{\mathrm{b}}$ & $60.1 \pm 1.5^{\mathrm{a}}$ & $14.8 \pm 1.7^{\mathrm{c}}$ \\
\hline
\end{tabular}

Data shown as mean $\pm \operatorname{SEM}(n=6)$, mean values with unlike superscript letters were significantly different $(p \leq 0.05)$

FAO (1983) limits in fresh muscle (mg/Kg): $\mathrm{Cd}(0.5), \mathrm{Cu}(30), \mathrm{Pb}(0.5)$ and $\mathrm{Zn}(30)$

EOS (1993) MPL limits in fish (mg/Kg): Cd (0.5), Cu (20), Pb (2) and Zn (40)
Also, concerning this aspect, $\mathrm{He}$ et al. 2012 found that the alkaline environment favors heavy metal accumulation in sediment. Water concentration of ammonia exceeds the permissible limits, and this may be attributed to the use of agricultural drainage water. In addition, the elevation of toxic unionized ammonia could explain the elevation of toxic nitrite, which is recorded in this study.

The elevated level of COD and the decreased level may be attributed to high organic matter, which can be deduced from the recorded increase in both unionized toxic ammonia and nitrite. According to the present study, it is found that total hardness values in summer were higher than those in winter. The increasing total hardness values at summer may be ascribed to the increase of salinity (Ali et al. 2016) as a result of evaporation of water due to the high temperature during this season.

Unionized ammonia (NH3) is extremely toxic substance to aquatic animals that retard fish growth and may increase their susceptibility to other unfavorable conditions in fish culture system (Boyed and Tucker, 1992). The concentration of ammonia in water exceeded the permissible limits. According to our results, heavy metal accumulation is generally more evident in liver than in muscle, as active metabolite organ accumulates higher amounts of heavy metal than muscle (Ben Salem et al. 2014). That in agreement with measurements obtained by Bayomy et al. (2015). The liver is known to be the active central site of metal uptake and storage, and it plays an important role in detoxification and excretion (Kim and Kang 2004). Moreover, the lowest concentrations of metals found in the muscle than in the liver may be due to the little blood supply to the muscular tissues (Kalkan et al. 2015). Thus, the liver is the most recommended tissue as an environmental indicator of water pollution (Henry et al. 2004).

As the muscle is the main edible part of fish and can directly influence human health, so heavy metal assessment in muscle is essential given that the flesh is destined for human consumption. The essential metals, such as zinc and copper, are in higher values, presumably due to their function as co-factors for the activation of a number of enzymes and regulated to maintain a certain homeostatic status in fish (Kumar et al. 2011). Although they are needed for the organisms' growth, they will be toxic if their concentrations exceed the allowable limit. In the present study, $\mathrm{Cu}$ and $\mathrm{Zn}$ (except in autumn) concentrations in fish muscle are below the permissible limits of the $\mathrm{FAO}$, while $\mathrm{Cu}$ concentrations exceeded these limits in liver tissue in spring and winter.

$\mathrm{Pb}$ and $\mathrm{Cd}$ are nonessential elements, described as xenobiotic, for living organism. $\mathrm{Pb}$ possesses various effects such as neuro- and nephro-toxicity, rapid behavioral malfunction, and decreases the growth, metabolism, and 

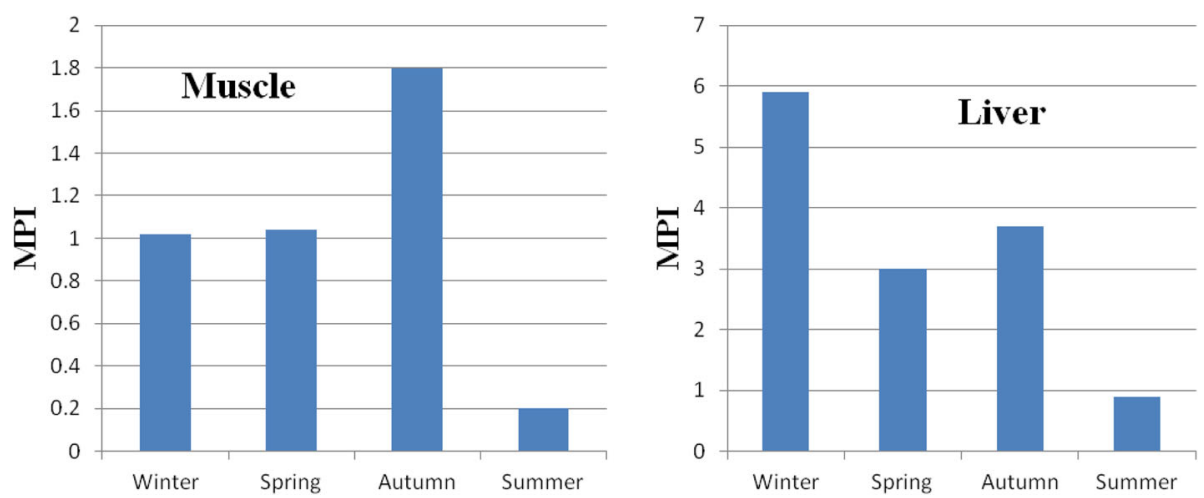

Fig. 1 Seasonal variations of metal pollution indices (MPI) in liver and muscle tissues of Oreochromis niloticus

survival rate, alteration of social behavior in some mammals (Garcia-Leston et al. 2010). According to our results, $\mathrm{Pb}$ was found to exceed the limits in both fish tissues (liver and muscle), coincide with Rashed (2001) who found that elevated $\mathrm{Pb}$ level in fishes obtained from freshwater ecosystem affected by extended agriculture, poultry farms, textile, industrial, and other activities. However, regarded sediments could be the major sources of $\mathrm{Pb}$ contamination. Excessive $\mathrm{Cd}$ exposure may give rise to renal, pulmonary, hepatic, skeletal, and reproductive toxicity effects and cancer (Rajeshkumar et al. 2018). Although Cd concentration in fish muscle in our study was found to be less than limits, a great attention should be taken as $\mathrm{Cd}$ may accumulate in humans via food chain magnification (Ben Salem et al. 2014).

According to the results obtained here, metal concentrations in fish liver exhibited seasonal variations in which higher metal pollution index (MPI) was that for fish collected in winter followed by autumn and spring and the lowest MPI was for fish collected in summer. These results are supported by El-Batrawy et al. (2018) and Bayomy et al. (2015), who recorded that average metal concentration in Oreochromis niloticus tissues in winter is higher than in summer. Also, Abd-El-Khalek et al. (2012)
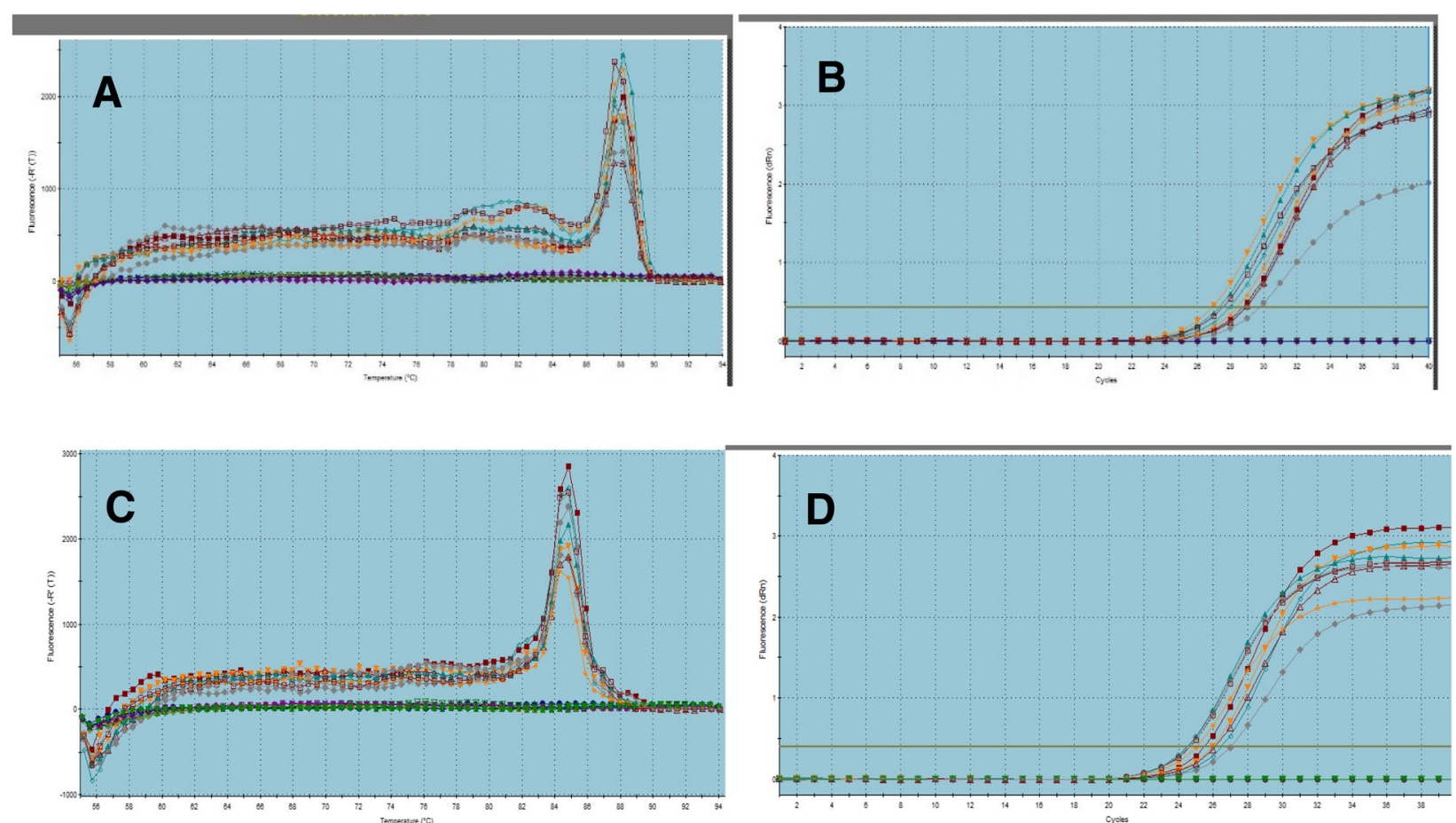

Fig. 2 Melting curve analysis showed a single peak for MT gene (a) and $\beta$-actin (c) gene. Representative amplification plot for MT gene (b) and $\beta$-actin gene $(\mathbf{d})$ 
Table 5 Pearson correlation between hepatic MT expression levels and metal concentrations in fish in different seasons

\begin{tabular}{lll}
\hline Metal & Correlation coefficient with MT expression & $p$ value \\
\hline $\mathrm{Pb}$ & $0.609^{* *}$ & $<0.001$ \\
$\mathrm{Zn}$ & 0.037 & 0.87 \\
$\mathrm{Cu}$ & $0.752^{* *}$ & $<0.001$ \\
\hline
\end{tabular}

${ }^{* *}$ Correlation is significant at the 0.01 level (two-tailed)

reported higher heavy metal accumulation in autumn than in summer. Conversely, Bahnasawy et al. (2009) demonstrated that heavy metal levels in summer were higher than in winter. Seasonal variations can be attributed to the increase or decrease of drainage water discharged into the farm (Bahnasawy et al. 2009).

On the other hand, different season-dependent conditions such as salinity, $\mathrm{pH}$ and hardness, dietary factors, and growth and reproductive cycles are also influential on metal accumulation in fish tissues (Yilmaz et al. 2010 and Saei-Dehkordi and Fallah 2011). A negative relation between hardness and alkalinity and heavy metal concentration in fish tissue. This result is in accordance with a study by Malcolm (1995), who revealed that at higher values of these variables the metals bind to form hydroxide and carbonate complexes which are considered less toxic to fish rather than the metal ions.

MT has been suggested to be a suitable biochemical indicator and its expression changes in fishes used as a biomarker for detecting the metal pollution in water. Although MT induction in fish is known to be high in tissues involved in metal uptake, storage and excretion, such as gills, liver, kidney, intestine, and muscle (Min et al. 2016), the highest concentration of MT was induced in the liver (Sevcikova et al. 2013). Liver measurement remains the most used since it reflects early exposure to contaminants because the liver is the main detoxification organ of the body (Jakimovska et al. 2011). Therefore, in the present study, the mRNA levels were evaluated in the liver of the

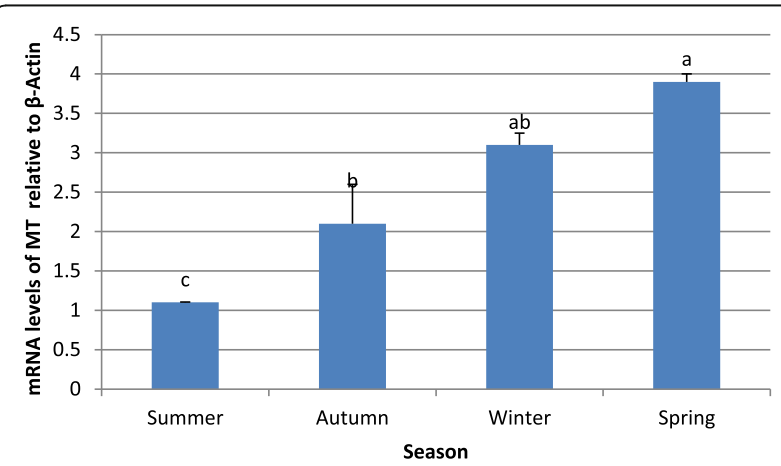

Fig. 3 Seasonal effect on mRNA expression levels of Metallothionein (MT) gene in liver tissue of Oreochromis niloticus. Bars indicate the standard error. Mean values with unlike superscript letters were significantly different $(p \leq 0.05)$ collected fish and since MT are involved in metal storage and detoxification processes, it is relevant to compare collected fish exposed to heavy metal pollution in their environment with fish living in sites considered to be unpolluted. MT normally occurs in tissues in trace amounts; however, exposure to metals induces its formation (Rajeshkumar et al. 2018). Our results reflected a significant increase in the mRNA levels of MT in liver tissue of fish collected from farms relative to the control that may be due to the heavy metals accumulation.

A few reports were conducted in Egypt regarding the use of MT gene expression in fish as a biomarker for detecting the metal pollution, such as Abumourad et al. (2014) who reported that Metallothionein was significantly highly expressed in liver tissue in response to heavy metal pollution. MT transcript and protein are induced in fish by a variety of bivalent metals, including cadmium, zinc, copper, and lead (Carginale et al. 1998; Riggioa et al. 2003).

The elevation of MT concentration in fishes by zinc exposure coincides with those of Zhang and Wang (2005) and that occurs only in higher exposure of $\mathrm{Zn}$. However, Butler and Roesijadi (2001) verified that $\mathrm{Cu}$ and $\mathrm{Cd}$ are the most inducers of MT than Zn. According to our results, $\mathrm{Cu}$ and $\mathrm{Pb}$ concentration differences were found to be significantly correlated with hepatic MT expression. This emphasized the role of MT as a biomarker for exposure of $\mathrm{Cu}$ and $\mathrm{Pb}$ in Oreochromis niloticus. In agreement with Juhari (2014), a significant increase in MT mRNA levels in Oreochromis niloticus induced by $\mathrm{Cu}$ and $\mathrm{Pb}$.

As proposed previously, the binding affinity of MT for $\mathrm{Cu}$ ions is bigger than other metal ions (Sakulsak 2012). As well Boeck et al. (2003) found that MT induction was partially attributed to the $\mathrm{Cu}$ regulation process and MTs may be in favor of $\mathrm{Cu}$ storage. Additionally, a positive correlation between the extent of $\mathrm{Cu}$ accumulation and MT concentration in in black sea bream (Dang et al. 2009). It was also observed an increase in hepatic $\mathrm{Cu}$ conjugated to MT proteins in perch exposed to $\mathrm{Cu}$ (Wang et al. 2014).

\section{Conclusion}

Our results indicated that MT gene expression seems to be induced by metal pollution especially $\mathrm{Cu}$ and $\mathrm{Pb}$; therefore, the appropriateness of MT as a marker of metal exposure in fish may be confident under field conditions. The results proved that the heavy metal accumulation in fish may vary depending on changes in the environmental conditions, that means that seasonal sources of heavy metals in fish is alarming as it will directly come into the human food chain and will affect the human health. In addition, cultured fish in this study could be unfit for human consumption due to a high 
level of $\mathrm{Pb}$ in the edible part of fish. Therefore, greater attention should be set to $\mathrm{Pb}$ sources accumulated in cultured fish in Kafr El-Sheikh governorate.

\section{Abbreviations}

ANOVA: Analysis of variance; CD: Cadmium; COD: Chemical oxygen demand; Cu: Cupper; DNA: Deoxyribonucleic acid; DO: Dissolved oxygen; ESO: Elder scrolls online; FAO: Food and Agriculture Organization; HCl: Hydrogen chloride; MPI: Metal pollution index; MT: Metallothionein; NH3: Ammonia; NO2: Nitrite; Pb: Lead; PCR: Polymerase chain reaction; RNA: Ribonucleic acid; TKN: Total kjeldahl nitrogen; Zn: Zinc

\section{Acknowledgements}

This work was supported and funded by the National Research Center, Giza, Egypt.

\section{Authors' contributions}

SMG designed this work, participated in laboratory analysis, and wrote with critical revision of the manuscript. DMM participated in laboratory analysis and wrote the manuscript. MIH completed the sample collection in the field and laboratory analysis and wrote the manuscript, AA was involved in reviewing the manuscript. All authors read and approved the final manuscript.

\section{Funding}

This work was funded by the National Research Centre, Giza, Egypt (Grant No: AR 111101).

\section{Availability of data and materials}

The authors declare that all data and materials are available.

\section{Ethics approval and consent to participate}

Did not do the ethics process for this work. All authors declare consent to participate.

\section{Consent for publication}

All authors declare that this manuscript is consent for publication.

\section{Competing interests}

The authors declare that they have no competing interests.

\section{Author details}

'Department of Cell Biology, Genet. Eng.\& Biotech. Res. Div., National Research Centre, 33 El-Bohouth St. Dokki, Giza P.O. 12622, Egypt. ${ }^{2}$ Department of Fish Diseases and Management, Fac. Vet. Med., Cairo University, Giza, Egypt.

Received: 1 June 2019 Accepted: 16 July 2019

Published online: 06 August 2019

\section{References}

Abd-El-Khalek DE, El-Gohary S, El-Zokm GM (2012) Assessment of heavy metals pollution in Oreochromis niloticus El-Max fish farm, Egypt. Egypt J Exp Biol (Zool) 8(2):215-222

Abumourad IMK, Abbas WT, Authman MMN, Girgis SM (2014) Environmental impact of heavy metal pollution on Metallothionein expression in Nile Tilapia. RJPBCS 5(2) page no. 998

Ali NA, Mohamed MA, Abd El-Hameed EAA (2016) Water quality and heavy metals monitoring in water and tissues of Nile tilapia fish from different governorates "Egyptian aquaculture farms". Egypt J Aquat Biol Fish 20(3): 103-113

Association of Official Analytical Chemists (AOAC) (2005) Official Method 999.11 of Analysis of lead, cadmium, copper, iron and zinc in foods. Atomic absorption spectrophotometry, Washington, D.C

APHA (2012) In: Greenberg AE, Clesceri LS, Eaton AD (eds) American public health association. Standard methods for the examination of water and wastewater, 18th edn. APHA, WEF \& AWWA, Washington DC

Ayas Z, Ekmekci G, Yerli SV, Ozmen M (2007) Heavy metal accumulation in water, sediments and fishes of Nallihan Bird Paradise. Turk J Environ Biol 28(3):545-549
Bahnasawy MH, Khidr AA, Dheina NA (2009) Assessment of heavy metals concentrations in water, plankton and fish of Lake Manzala, Egypt. Egypt 」 Aquat Biol Fish 13(2):117-133

Bayomy HM, Rozan MA, Ziena HM (2015) Lead and cadmium contents in Nilewater, Tilapia and catfish from Rosetta branch, river Nile, Egypt. J Food Dairy Sci Mansoura Univ 6(4):253-262

Begum A, Mustafa Al, Amin N, Chowdhury TR, Quraishi SB, Banu N (2013) Levels of heavy metals in tissues of shingi fish (Heteropneustes fossilis) from Buriganga River, Bangladesh. Environ Monit Assess 185:5461-5469

Ben Salem Z, Capelli N, Laffray X, Ayadi H (2014) Seasonal variation of heavy metals in water, sediment and roach tissues in a landfill draining system pond (Etueffont, France). Ecol Eng 69:25-37

Boeck GD, Ngo TTH, Campenhout KV, Blust R (2003) Differential metallothionein induction patterns in three fresh water fish during sublethal copper exposure. Aquat Toxicol 65:413-424

Boyed CE, Tucker CS (1992) Water quality and pond soil analysis for aquaculture. Alabama Agriculture Experiment Station. Auburn University, Ala, p 183

Burger J, Gochfeld M (2005) Heavy metals in commercial fish in New Jersey. Environ Res 99:403-412

Butler RA, Roesijadi G (2001) Disruption of Metallothionein expression with antisense oligonucleotides abolishes protection against cadmium cytotoxicity in molluscan hemocytes. Toxicol Sci 59:101-107

Carginale V, Scudiero R, Capasso C, Capasso A, Kille A, Di Prisco G, Parisi E (1998) Cadmium-induced differential accumulation of metallothionein isoforms in the Antarctic ice fish, which exhibits no basal metallothionein protein but high endogenous mRNA levels. Biochem J 332:475-481

Dang F, Zhong H, Wang WX (2009) Copper uptake kinetics and regulation in a marine fish after waterborne copper acclimation. Aquat Toxicol 94:238-244

Egyptian Governmental Law No. 48/1982- Decision 92 (2013) The implementer regulations for Law 48/1982, Decision 92/2013 regarding the protection of the River Nile and water ways from pollution. Map Periodical Bull., 21-30

El-Batrawy OA, El-Gammal MI, Mohamadein LI, Darwish DH, El-Moselhy KM (2018) Impact assessment of some heavy metals on tilapia fish, Oreochromis niloticus, in Burullus Lake, Egypt. J Basic Appl Zool 79:13

EOS (Egyptian Organization for Standardization, Egypt) (1993) Egyptian standard, maximum levels for heavy metal concentrations in food. ES 2360-1993, UDC: 46.19:815

FAO (1983) Compilation of legal limits for hazardous substances in fish and fishery products. FAO Fish Circ 464:5-100 Nauen CE. Ed.

Garcia-Leston J, Mendez J, Pasaro E, Laffon B (2010) Genotoxic effects of lead: an updated review. Environ Int 36:623-636

He SL, Li CJ, Pan ZP, Luo MX, Meng W et al (2012) Geochemistry and environmental quality assessment of Hongfeng Lake sediments, Guiyang. Geophys Geochem Explor 36:273-297 (in Chinese)

Henry F, Amara R, Couture LD, Bertho ML (2004) Heavy metals in four fish species from the French coast of the Eastern English Channel and Southern Bight of the North Sea. Environ Int 30:675-683

Isani G, Carpenè E (2014) Metallothioneins, unconventional proteins from unconventional animals: a long journey from nematodes to mammals. Biomolecules 4(2):435-457

Jakimovska A, Konieczka P, Skóra K, Namieśnik J (2011) Bioaccumulation of metals in tissues of marine animals, part I: the role and impact of heavy metals on organisms. Pol J Environ Stud 20(5):1117-1125

Juhari EL (2014) Metallothionein gene expression and genotoxic effects of heavy metals on Oreochromis sp. MSc, Fac Sci, University Of Malaya, Kualalumpur

Kalkan H, Şişman T, Kllı̧ D (2015) Assessment of heavy metal bioaccumulation in some tissues of Leuciscus Cephalus from Karasu River, Erzurum-Turkey. Austin J Environ Toxicol 1(1):1004

Kim SG, Kang JC (2004) Effect of dietary copper exposure on accumulation, growth and hematological parameters of the juvenile rockfish, Sebastes schlegeli. Mar Environ Res 58:65-82

Kumar B, Mukherjee DP, Kumar S, Mishra M, Prakash D, Singh SK, Sharma CS (2011) Bioaccumulation of heavy metals in muscle tissue of fishes from selected aquaculture ponds in East Kolkata wetlands. Annal Biol Res 2(5):125-134

Livak KJ, Schmittgen TD (2001) Analysis of relative gene expression data using real-time quantitative PCR and the $2^{-\Delta \Delta C t}$ method. Methods 25(4):402-408

Malcolm J (1995) Test book of environmental biology of fishes, 1st edn. Cornwall, Padstow Printed in Great Britain by T.j. press (padstow) LTD

Min EY, Ahn TY, Kang JC (2016) Bioaccumulation, alterations of metallothionein, and antioxidant enzymes in the mullet Mugil cephalus exposed to hexavalent chromium. Fish Aquat Sci 19:19 
OATA (Ornamental Aquatic Trade Association) (2008) Water quality criteriaornamental fish. Company limited by guarantee and registered in England no 2738119. Registered Office Wessex House, Westbury

Rajeshkumar S, Liu Y, Zhang X, Ravikumar B, Bai G, Li X (2018) Studies on seasonal pollution of heavy metals in water, sediment, fish and oyster from the Meiliang Bay of Tainu Lake in China. Chemosphere 191:626-638

Rashed MN (2001) Monitoring of environmental heavy metals in fish from Nasser Lake. Environ Int 2:27-33

Riggioa M, Filosaa S, Parisib E, Scudieroa R (2003) Changes in zinc, copper and metallothionein contents during oocyte growth and early development of the teleost Daniorerio (zebrafish). Comparat Biochem Physiol Part C Toxicol Pharmacol 135(2):191-196

Rishi KK, Jain M (1998) Effect of toxicity of cadmium on scale morphology in Cyprinus carpio (Cyprinidae). Bull Environ Contam Toxicol 60:323-328

Saei-Dehkordi SS, Fallah AA (2011) Determination of copper, lead, cadmium and zinc content in commercially valuable fish species from the Persian Gulf using derivative potentiometric stripping analysis. Microchem J 98:156-162

Sakulsak N (2012) Metallothionein. An overview on its metal homeostatic regulation in mammals. Int J Morphol 30(3):1007-1012

Santhosh B, Singh NP (2007) Guidelines for water quality management for fish culture in Tripura, ICAR research complex for NEH region, Tripura center, publication no.29

Sevcikova M, Modra H, Kruzikova K, Zitka O (2013) Effect of metals on Metallothionein content in fish from Skalka and Želivka reservoirs. Int 」 Electrochem Sci 8:1650-1663

Solaraj G, Dhanakumar S, Murthy KR, Mohanraj R (2010) Water quality in select regions of Cauvery Delta River basin, southern India, with emphasis on monsoonal variation. Environ Monit Assess 166:435-444

Struve C, Bojer M, Nielsen EM, Hansen DS, Krogfelt KA (2005) Investigation of the putative virulence gene magA in a worldwide collection of 495 Klebsiella isolates: magA is restricted to the gene cluster of Klebsiellapneumoniae capsule serotype K1. J Med Microbiol 54:1111-1113

Tulasi SJ, Reddy PUM, Rao RJV (1989) Effects of lead on the spawning potential of the freshwater fish, Anabas testudineus. Bull Environ Contam Toxicol 43:858-863

Usero J, Gonzales-Regalado E, Gracia I (1997) Trace metals in bivalve mollusks, Ruditapes decussatus and Ruditapes from the Atlantic Coast of southern Spain. Environ Int J23(3):291-298

Verlecar XN, Desai SR, Sarkar A, Dalal SG (2006) Biological indicators in relation to coastal pollution along Karnataka coast. Water Res 40:3304-3312

Wang WC, Mao H, Ma DD, Yang WX (2014) Characteristics, functions, and applications of metallothionein in aquatic vertebrates. Front Mar Sci. https:// doi.org/10.3389/fmars.2014.00034

Wepener V, Vanvuren JHJ, Du Preez HH (2001) Uptake and distribution of a copper, iron and zinc mixture in gill, liver and plasma of a freshwater teleost, Tilapia sparmanii. Water SA 27(1):99-108

Xia X, Chen X, Liu R, Liu H (2011) Heavy metals in urban soils with various types of land use in Beijing, China. J Hazard Mater 186:2043-2050

Yilmaz AB, Sangün MK, Yağlığlu D, Turan C (2010) Metals (major, essential to non-essential) composition of the different tissues of three demersal fish species from Iskenderun Bay, Turkey. Food Chem 123:410-415

Zhang L, Wang WX (2005) Effects of Zn pre-exposure on $\mathrm{cd}$ and Zn bioaccumulation and metallothionein levels in two species of marine fish. Aquat Toxicol 73(4):353-369

\section{Publisher's Note}

Springer Nature remains neutral with regard to jurisdictional claims in published maps and institutional affiliations.

\section{Submit your manuscript to a SpringerOpen ${ }^{\circ}$ journal and benefit from:}

- Convenient online submission

- Rigorous peer review

- Open access: articles freely available online

- High visibility within the field

- Retaining the copyright to your article

Submit your next manuscript at $\boldsymbol{\nabla}$ springeropen.com 